\title{
Genesis of Suicide Terrorism
}

\author{
Scott Atran
}

Contemporary suicide terrorists from the Middle East are publicly deemed crazed cowards bent on senseless destruction who thrive in poverty and ignorance. Recent research indicates they have no appreciable psychopathology and are as educated and economically well-off as surrounding populations. A first line of defense is to get the communities from which suicide attackers stem to stop the attacks by learning how to minimize the receptivity of mostly ordinary people to recruiting organizations.

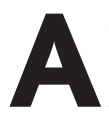
ccording to the U.S. Department of State report Patterns of Global Terrorism 2001 (1), no single definition of terrorism is universally accepted; however, for purposes of statistical analysis and policymaking: “The term 'terrorism' means premeditated, politically motivated violence perpetrated against noncombatant targets by subnational groups or clandestine agents, usually intended to influence an audience." Of course, one side's "terrorists" may well be another side's "freedom fighters" (Fig. 1). For example, in this definition's sense, the Nazi occupiers of France rightly denounced the "subnational" and "clandestine" French Resistance fighters as terrorists. During the 1980s, the International Court of Justice used the U.S. Administration's own definition of terrorism to call for an end to U.S. support for "terrorism" on the part of Nicaraguan Contras opposing peace talks.

For the U.S. Congress, " 'act of terrorism' means an activity that-(A) involves a violent act or an act dangerous to human life that is a violation of the criminal laws of the United States or any State, or that would be a criminal violation if committed within the jurisdiction of the United States or of any State; and (B) appears to be intended (i) to intimidate or coerce a civilian population; (ii) to influence the policy of a government by intimidation or coercion; or (iii) to affect the conduct of a government by assassination or kidnapping." (2). When suitable, the definition can be broadened to include states hostile to U.S. policy.

Apparently, two official definitions of terrorism have existed since the early 1980s: that used by the Department of State "for statistical and analytical purposes" and that used by Congress for criminal proceedings. Together, the definitions allow great flexibil-

CNRS-Institut Jean Nicod, 1 bis Avenue Lowendal, 75007 Paris, France, and Institute for Social Research, University of Michigan, Ann Arbor, MI 48106-1248, USA. E-mail: satran@umich.edu ity in selective application of the concept of terrorism to fluctuating U.S. priorities. The special category of "State-sponsored terrorism" could be invoked to handle some issues (3), but the highly selective and politically tendentious use of the label terrorism would continue all the same. Indeed, there appears to be no principled distinction between "terror" as defined by the U.S. Congress and "counterinsurgency" as allowed in U.S. armed forces manuals (4).

Rather than attempt to produce a stipulative and all-encompassing definition of terrorism, this article restricts its focus to "suicide terrorism" characterized as follows: the targeted use of self-destructing humans against noncombatant-typically civilian-populations to effect political change. Although a suicide attack aims to physically destroy an initial target, its primary use is typically as a weapon of psychological warfare intended to affect a larger public audience. The primary target is not those actually killed

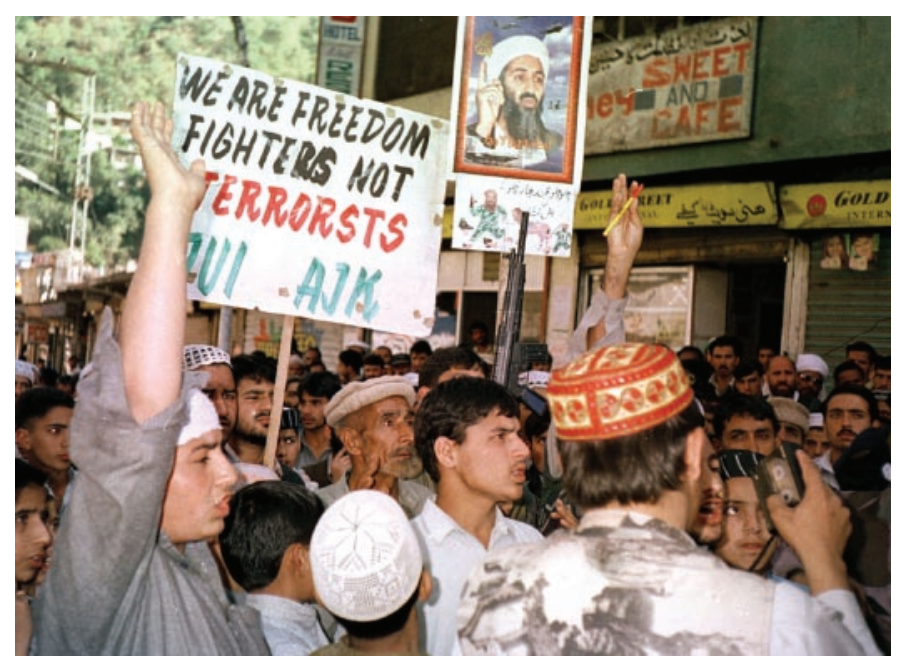

Fig. 1. Chanting demonstrators in Pakistan-held Kashmir defending Osama bin Laden's actions and ambitions as freedom-fighting (November 2001). [AP Photo/Roshan Mugal] or injured in the attack, but those made to witness it. The enemy's own information media amplify the attack's effects to the larger target population. Through indoctrination and training and under charismatic leaders, selfcontained suicide cells canalize disparate religious or political sentiments of individuals into an emotionally bonded group of fictive kin who willfully commit to die spectacularly for one another and for what early Christian Crusades are legendary ex- is perceived as the common good of alleviating the community's onerous political and social realities.

\section{Recent History}

Suicide attack is an ancient practice with a modern history (supporting online text). Its use by the Jewish sect of Zealots (sicari) in Roman-occupied Judea and by the Islamic Order of Assassins (hashashin) during the amples (5). The concept of "terror" as systematic use of violence to attain political ends was first codified by Maximilien Robespierre during the French Revolution. He deemed it an "emanation of virtue" that delivers "prompt, severe, and inflexible" justice, as "a consequence of the general principle of democracy applied to our country's most pressing needs." (6). The Reign of Terror, during which the ruling Jacobin faction exterminated thousands of potential 
materially stronger foes when fighting methods of lesser cost seem unlikely to succeed. Choice is often voluntary, but typically under conditions of group pressure and charismatic leadership. Thus, the kamikaze ("divine wind") first used in the battle of the Philippines (November 1944) were young, fairly well educated pilots who understood that pursuing conventional warfare would likely end in defeat. When collectively asked by Adm. Takijiro Onishi to volunteer for "special attack" (tokkotai) "transcending life and death," all stepped forward, despite assurances that refusal would carry no shame or punishment. In the Battle of Okinawa (April 1945) some 2000 kamikaze rammed fully fueled fighter planes into more than 300 ships, killing 5000 Americans in the most costly naval battle in U.S. history. Because of such losses, there was support for using the atomic bomb to end World War II (7).

The first major contemporary suicide terrorist attack in the Middle East was the December 1981 destruction of the Iraqi embassy in Beirut (27 dead, over 100 wounded). Its precise authors are still unknown, although it is likely that Ayatollah Khomeini approved its use by parties sponsored by Iranian intelligence. With the assassination of pro-Israeli Lebanese President Bashir Gemayel in September 1982, suicide bombing became a strategic political weapon. Under the pro-Iranian Lebanese Party of God (Hezbollah), this strategy soon achieved geopolitical effect with the October 1983 truck-bomb killing of nearly 300 American and French servicemen. American and France abandoned the multinational force policing Lebanon. By 1985 , these attacks arguably led Israel to cede most of the gains made during its 1982 invasion of Lebanon.

In Israel-Palestine, suicide terrorism began in 1993, with attacks by Hezbollahtrained members of the Islamic Resistance Movement (Hamas) and Palestine Islamic Jihad (PIJ) aimed at derailing the Oslo Peace Accords (8). As early as 1988, however, PIJ founder Fathi Shiqaqi established guidelines for "exceptional" martyrdom operations involving human bombs. He followed Hezbollah in stressing that God extols martyrdom but abhors suicide: "Allah may cause to be known those who believe and may make some of you martyrs, and Allah may purify those who believe and may utterly destroy the disbelievers"; however, "no one can die except by Allah's leave" $(9,10)$ (Fig. 2).

The recent radicalization and networking through Al-Qaida of militant Islamic groups from North Africa, Arabia, and Central and Southeast Asia stems from the Soviet-Afghan War (1979-1989). With financial backing from the United States, members of these various groups were provided opportunities to pool and to unify doctrine, aims, training, equipment, and methods, including suicide attack. Through its multifaceted association with regional groups (by way of finance, personnel, and logistics), Al-Qaida aims to realize flexibly its

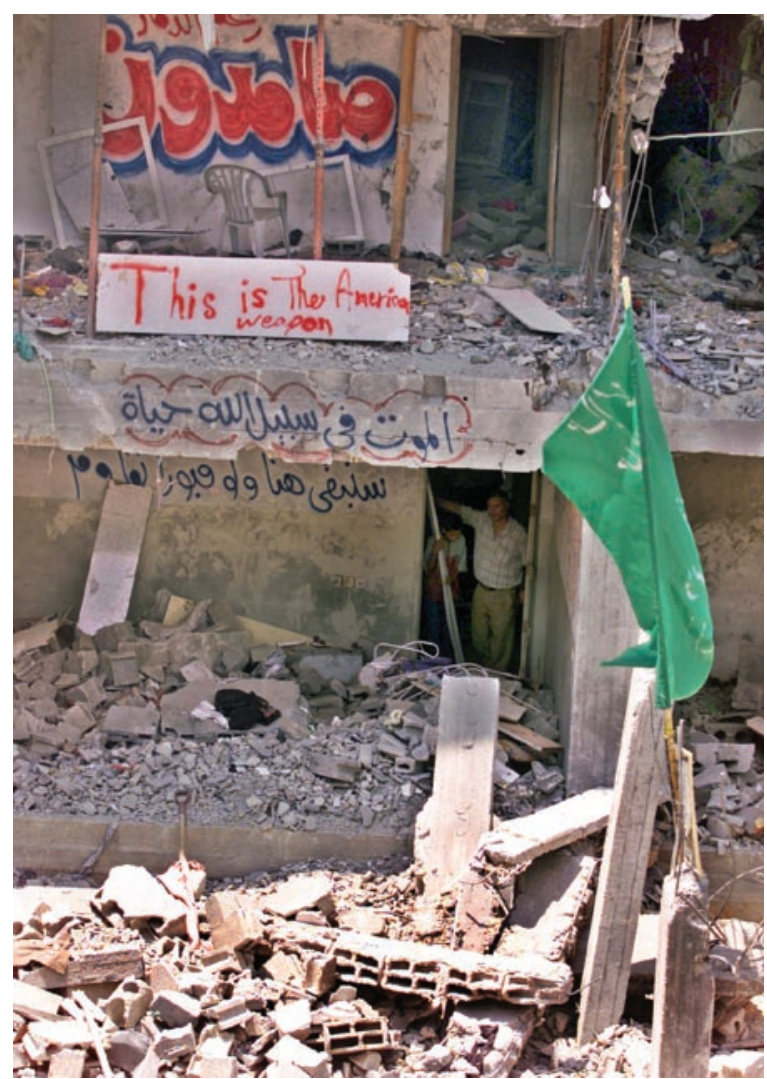

Fig. 2. Wreckage in Gaza after an Israeli attack that killed Salah Shehadeh, Hamas military commander. It features the green Hamas flag, and Arabic graffiti reads: "We are resisters, death in the way of Allah is the life." [AP Photo/Adel Hana]

global ambition of destroying Western dominance through local initiatives to expel Western influences (11). According to Jane's Intelligence Review: "All the suicide terrorist groups have support infrastructures in Europe and North America." (12).

Calling the current wave of radical Islam "fundamentalism" (in the sense of "traditionalism") is misleading, approaching an oxymoron (supporting online text). Present-day radicals, whether Shi'ite (Iran, Hezbollah) or Sunni (Taliban, Al-Qaida), are much closer in spirit and action to Europe's post-Renaissance Counter-Reformation than to any traditional aspect of Moslem history. The idea of a ruling ecclesiastical authority, a state or national council of clergy, and a religious police devoted to physically rooting out heretics and blasphemers has its clearest historical model in the Holy Inquisition. The idea that religion must struggle to assert control over politics is radically new to Islam (13).

\section{Dubious Public Perceptions}

Recent treatments of Homeland Security research concentrate on how to spend billions to protect sensitive installations from attack (14, 15). But this last line of defense is probably easiest to breach because of the multitude of vulnerable and likely targets (including discotheques, restaurants, and malls), the abundance of would-be attackers (needing little supervision once embarked on a mission), the relatively low costs of attack (hardware store ingredients, no escape needs), the difficulty of detection (little use of electronics), and the unlikelihood that attackers would divulge sensitive information (being unaware of connections beyond their operational cells). Exhortations to put duct tape on windows may assuage (or incite) fear, but will not prevent massive loss of life, and public realization of such paltry defense can undermine trust. Security agencies also attend to prior lines of defense, such as penetrating agent-handling networks of terrorist groups, with only intermittent success.

A first line of defense is to prevent people from becoming terrorists. Here, success appears doubtful should current government and media opinions about why people become human bombs translate into policy (see also supporting online text on contrary academic explanations). Suicide terrorists often are labeled crazed cowards bent on senseless destruction who thrive in the midst of poverty and ignorance. The obvious course becomes to hunt down terrorists while simultaneously transforming their supporting cultural and economic environment from despair to hope. What research there is, however, indicates that suicide terrorists have no appreciable psychopathology and are at least as educated and economically well off as their surrounding populations.

\section{Psychopathology: A Fundamental Attribution Error}

U.S. President George W. Bush initially branded 9/11 hijackers "evil cowards." For U.S. Senator John Warner, preemptive assaults on terrorists and those supporting terrorism are justified because: "Those who would commit suicide in their assaults on the free world are not rational and are not deterred by rational concepts" (16). In attempting to counter anti-Moslem sentiment, some 


\section{RE V IE W}

groups advised their members to respond that "terrorists are extremist maniacs who don't represent Islam at all" (17).

Social psychologists have investigated the "fundamental attribution error," a tendency for people to explain behavior in terms of individual personality traits, even when significant situational factors in the larger society are at work. U.S. government and media characterizations of Middle East suicide bombers as craven homicidal lunatics may suffer from a fundamental attribution error: No instances of religious or political suicide terrorism stem from lone actions of cowering or unstable bombers.

Psychologist Stanley Milgram found that ordinary Americans also readily obey destructive orders under the right circumstances (18). When told by a "teacher" to administer potentially life-threatening electric shocks to "learners" who fail to memorize word pairs, most comply. Even when subjects stressfully protest as victims plead and scream, use of extreme violence continues - not because of murderous tendencies but from a sense of obligation in situations of authority, no matter how trite. A legitimate hypothesis is that apparently extreme behaviors may be elicited and rendered commonplace by particular historical, political, social, and ideological contexts.
With suicide terrorism, the attributional problem is to understand why nonpathological individuals respond to novel situational factors in numbers sufficient for recruiting organizations to implement policies. In the Middle East, perceived contexts in which suicide bombers and supporters express themselves include a collective sense of historical injustice, political subservience, and social humiliation vis-à-vis global powers and allies, as well as countervailing religious hope (supporting online text on radical Islam's historical novelty). Addressing such perceptions does not entail accepting them as simple reality; however, ignoring the causes of these perceptions risks misidentifying causes and solutions for suicide bombing.

There is also evidence that people tend to believe that their behavior speaks for itself, that they see the world objectively, and that only other people are biased and misconstrue events (19). Moreover, individuals tend to misperceive differences between group norms as more extreme than they really are. Resulting misunderstandings - encouraged by religious and ideological propaganda-lead antagonistic groups to interpret each other's views of events, such as terrorism/freedom-fighting,
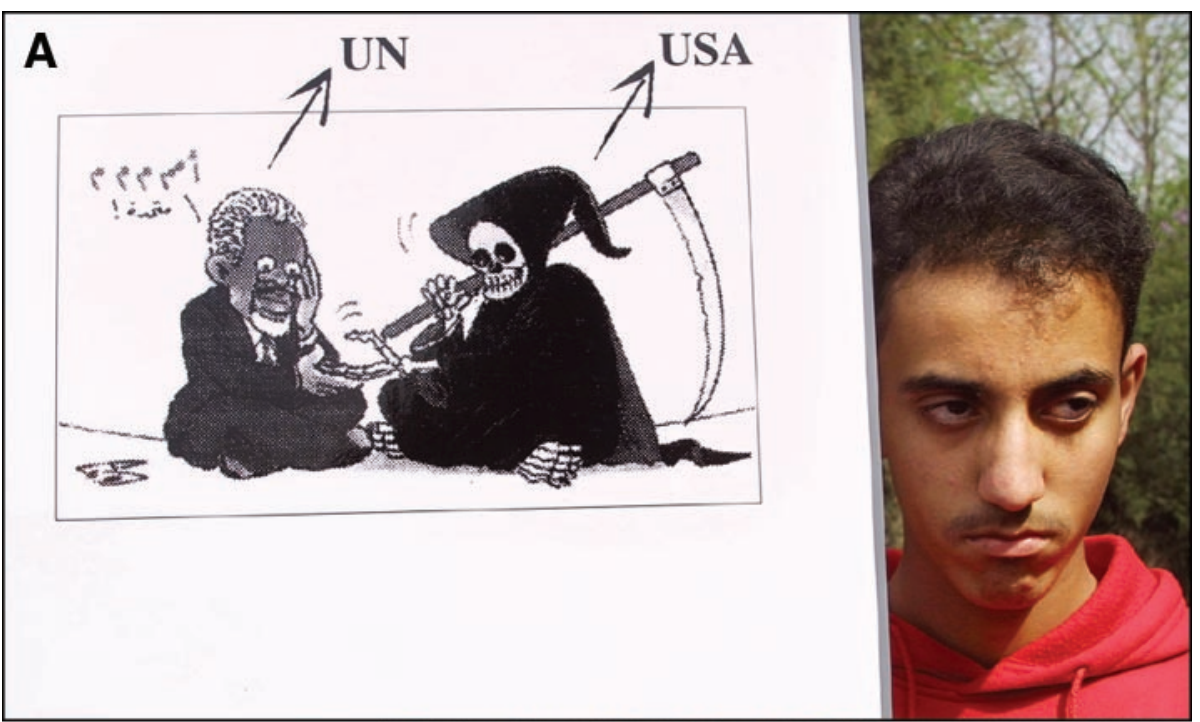

Fig. 3. Demonization works both ways. (A) Demonstrator's placard outside the Palestinian embassy in Beijing vilifying the United Nations and the United States (April 2002). [Reuters/Andrew Wong] (B) Anti-Moslem sign outside Jacksonville, Florida, church (January 2003). [Photo courtesy of Florida TimesUnion]

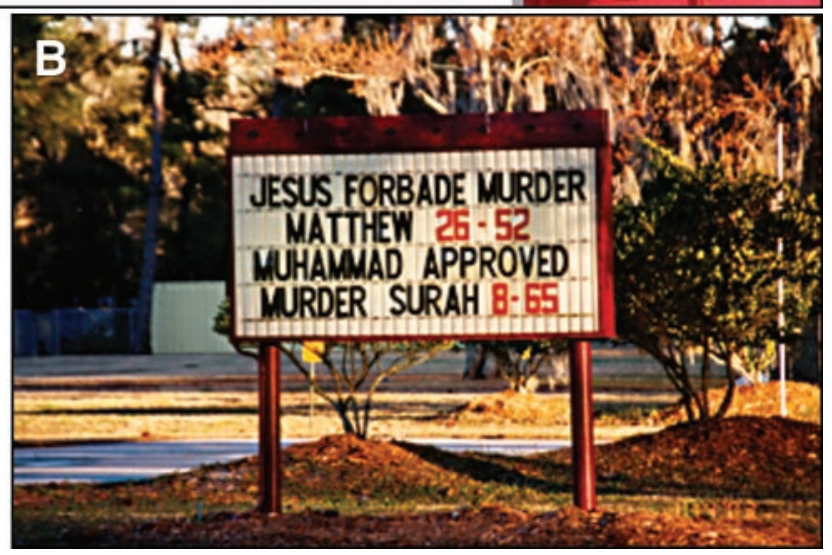

as wrong, radical, and/or irrational. Mutual demonization and warfare readily ensue. The problem is to stop this spiral from escalating in opposing camps (Fig. 3).

\section{Poverty and Lack of Education Are Not Reliable Factors}

Across our society, there is wide consensus that ridding society of poverty rids it of crime (20). According to President Bush, "We fight poverty because hope is the answer to terror. ... We will challenge the poverty and hopelessness and lack of education and failed governments that too often allow conditions that terrorists can seize" (21). At a gathering of Nobel Peace Prize laureates, South Africa's Desmond Tutu and South Korea's Kim Dae Jong opined, "at the bottom of terrorism is poverty"; Elie Wiesel and the Dalai Lama concluded, "education is the way to eliminate terrorism" (22).

Support for this comes from research pioneered by economist Gary Becker showing that property crimes are predicted by poverty and lack of education (23). In his incentivebased model, criminals are rational individuals acting on self-interest. Individuals choose illegal activity if rewards exceed probability of detection and incarceration together with expected loss of income from legal activity ("opportunity costs"). Insofar as criminals lack skill and education, as in much bluecollar crime, opportunity costs may be minimal; so crime pays.

Such rational-choice theories based on economic opportunities do not reliably account for some types of violent crimes (domestic homicide, hate killings). These calculations make even less sense for suicide terrorism. Suicide terrorists generally are not lacking in legitimate life opportunities relative to their general population. As the Arab press emphasizes, if martyrs had nothing to lose, sacrifice would be senseless (24): "He who commits suicide kills himself for his own benefit, he who commits martyrdom sacrifices himself for the sake of his religion and his nation.... The Mujahed is full of hope" (25).

Research by Krueger and Maleckova suggests that education may be uncorrelated, or even positively correlated, with supporting terrorism (26). In a December 2001 poll of 1357 West Bank and Gaza Palestinians 18 years of age or older, those having 12 or more years of schooling supported armed attacks by 68 points, those with up to 11 years of schooling by 63 points, and illiterates by 46 points. Only $40 \%$ of persons with advanced degrees supported dialogue with Israel versus 53\% with college degrees and $60 \%$ with 9 years or less of schooling. In a comparison of Hezbollah militants who died in action with a random sample of Lebanese from the same age group and region, militants were less likely to come from poor 
homes and more likely to have had secondaryschool education.

Nevertheless, relative loss of economic or social advantage by educated persons might encourage support for terrorism. In the period leading to the first Intifada (1982-1988), the number of Palestinian men with 12 years or more of schooling more than doubled; those with less schooling increased only $30 \%$. This coincided with a sharp increase in unemployment for college graduates relative to high school graduates. Real daily wages of college graduates fell some $30 \%$; wages for those with only secondary schooling held steady. Underemployment also seems to be a factor among those recruited to Al-Qaida and its allies from the Arabian peninsula (27).

\section{The Institutional Factor: Organizing Fictive Kin}

Although humiliation and despair may help account for susceptibility to martyrdom in some situations, this is neither a complete explanation nor one applicable to other circumstances. Studies by psychologist Ariel Merari point to the importance of institutions in suicide terrorism (28). His team interviewed 32 of 34 bomber families in Palestine/Israel (before 1998), surviving attackers, and captured recruiters. Suicide terrorists apparently span their population's normal distribution in terms of education, socioeconomic status, and personality type (introvert vs. extrovert). Mean age for bombers was early twenties. Almost all were unmarried and expressed religious belief before recruitment (but no more than did the general population).

Except for being young, unattached males, suicide bombers differ from members of violent racist organizations with whom they are often compared (29). Overall, suicide terrorists exhibit no socially dysfunctional attributes (fatherless, friendless, or jobless) or suicidal symptoms. They do not vent fear of enemies or express "hopelessness" or a sense of "nothing to lose" for lack of life alternatives that would be consistent with economic rationality. Merari attributes primary responsibility for attacks to recruiting organizations, which enlist prospective candidates from this youthful and relatively unattached population. Charismatic trainers then intensely cultivate mutual commitment to die within small cells of three to six members. The final step before a martyrdom operation is a formal social contract, usually in the form of a video testament.

From 1996 to 1999 Nasra Hassan, a Pakistani relief worker, interviewed nearly 250 Palestinian recruiters and trainers, failed suicide bombers, and relatives of deceased bombers. Bombers were men aged 18 to 38 : "None were uneducated, desperately poor, simple-minded, or depressed. ... They all seemed to be entirely normal members of their families" (30). Yet "all were deeply religious," believing their actions "sanctioned by the divinely revealed religion of Islam." Leaders of sponsoring organizations complained, "Our biggest problem is the hordes of young men who beat on our doors."

Psychologist Brian Barber surveyed 900 Moslem adolescents during Gaza's first Intifada (1987-1993) (31). Results show high levels of participation in and victimization from violence. For males, $81 \%$ reported throwing stones, $66 \%$ suffered physical assault, and $63 \%$ were shot at (versus 51, 38, and $20 \%$ for females). Involvement in violence was not strongly correlated with depression or antisocial behavior. Adolescents most involved displayed strong individual pride and social cohesion. This was reflected in activities: for males, $87 \%$ delivered supplies to activists, $83 \%$ visited martyred families, and $71 \%$ tended the wounded $(57,46$, and $37 \%$ for females $)$. A follow-up during the second Intifada (2000-2002) indicates that those still unmarried act in ways considered personally more dangerous but socially more meaningful. Increasingly, many view martyr acts as most meaningful. By summer 2002, 70 to $80 \%$ of Palestinians endorsed martyr operations (32).

Previously, recruiters scouted mosques, schools, and refugee camps for candidates deemed susceptible to intense religious indoctrination and logistical training. During the second Intifada, there has been a surfeit of volunteers and increasing involvement of secular organizations (allowing women). The frequency and violence of suicide attacks have escalated (more bombings since February 2002 than during 1993-2000); planning has been less painstaking. Despite these changes, there is little to indicate overall change in bomber profiles (mostly unmarried, average socioeconomic status, moderately religious) $(28,30)$.

In contrast to Palestinians, surveys with a control group of Bosnian Moslem adolescents from the same time period reveal markedly weaker expressions of self-esteem, hope for the future, and prosocial behavior (30). A key difference is that Palestinians routinely invoke religion to invest personal trauma with proactive social meaning that takes injury as a badge of honor. Bosnian Moslems typically report not considering religious affiliation a significant part of personal or collective identity until seemingly arbitrary violence forced awareness upon them.

Thus, a critical factor determining suicide terrorism behavior is arguably loyalty to intimate cohorts of peers, which recruiting organizations often promote through religious communion (supporting online text on reli- gion's role) (33). Consider data on 39 recruits to Harkat al-Ansar, a Pakistani-based ally of Al-Qaida. All were unmarried males, most had studied the Quran. All believed that by sacrificing themselves they would help secure the future of their "family" of fictive kin: "Each [martyr] has a special place-among them are brothers, just as there are sons and those even more dear" (34). A Singapore Parliamentary report on 31 captured operatives from Jemaah Islamiyah and other AlQaida allies in Southeast Asia underscores the pattern: "These men were not ignorant, destitute or disenfranchised. All 31 had received secular education. . . Like many of their counterparts in militant Islamic organizations in the region, they held normal, respectable jobs.... As a group, most of the detainees regarded religion as their most important personal value... secrecy over the true knowledge of jihad, helped create a sense of sharing and empowerment vis-à-vis others." (35).

Such sentiments characterize institutional manipulation of emotionally driven commitments that may have emerged under natural selection's influence to refine or override short-term rational calculations that would otherwise preclude achieving goals against long odds. Most typically, such emotionally driven commitments serve as survival mechanisms to inspire action in otherwise paralyzing circumstances, as when a weaker person convincingly menaces a stronger person into thinking twice before attempting to take advantage. In religiously inspired suicide terrorism, however, these emotions are purposely manipulated by organizational leaders, recruiters, and trainers to benefit the organization rather than the individual (supporting online text on religion) (36).

\section{Rational Choice Is the Sponsor's Prerogative, Not the Agent's}

Little tangible benefit (in terms of rationalchoice theories) accrues to the suicide bomber, certainly not enough to make the likely gain one of maximized "expected utility." Heightened social recognition occurs only after death, obviating personal material benefit. But for leaders who almost never consider killing themselves (despite declarations of readiness to die), material benefits more likely outweigh losses in martyrdom operations. Hassan cites one Palestinian official's prescription for a successful mission: "a willing young man. .. nails, gunpowder, a light switch and a short cable, mercury (readily obtainable from thermometers), acetone .... The most expensive item is transportation to an Israeli town" (30). The total cost is about $\$ 150$.

For the sponsoring organization, suicide bombers are expendable assets whose losses generate more assets by expanding public 


\section{RE V IE W}

support and pools of potential recruits. Shortly after 9/11, an intelligence survey of educated Saudis (ages 25 to 41) concluded that 95\% supported Al-Qaida (37). In a December 2002 Pew Research Center survey on growing anti-Americanism, only 6\% of Egyptians viewed America and its "War on Terror" favorably (38). Money flows from those willing to let others die, easily offsetting operational costs (training, supporting personnel, safe houses, explosives and other arms, trans-

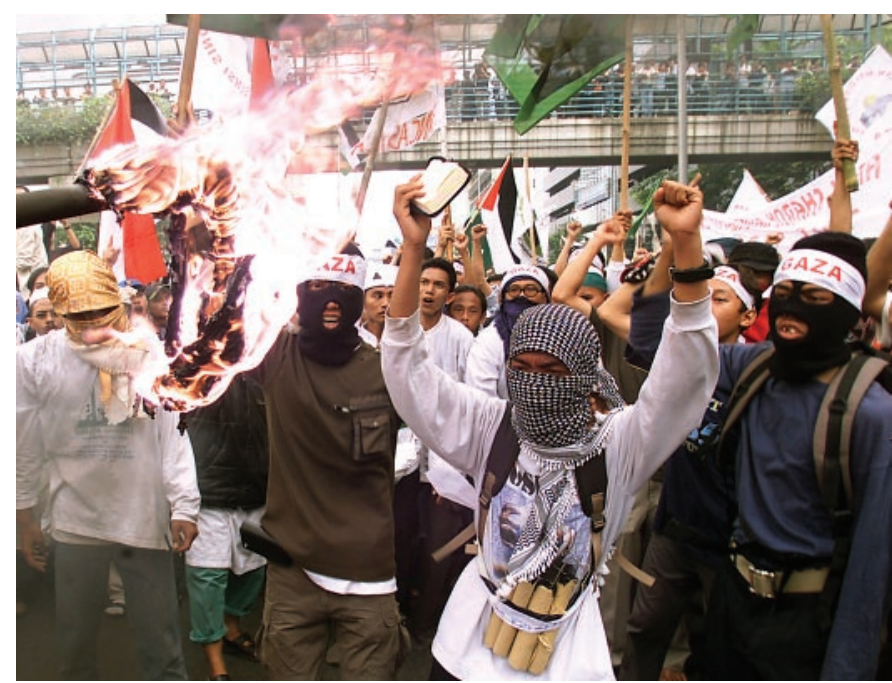

Fig. 4. Moslem youth with Quran dressed as a Palestinian suicide bomber demonstrating outside the United Nations office in Jakarta, Indonesia (April 2002). (Indonesia is the most populous Moslem nation.) [Reuters/ Darren Whiteside]

portation, and communication). After a Jerusalem supermarket bombing by an 18 year-old Palestinian female, a Saudi telethon raised more than $\$ 100$ million for "the AlQuds Intifada."

Massive retaliation further increases people's sense of victimization and readiness to behave according to organizational doctrines and policies structured to take advantage of such feelings. In a poll of 1179 West Bank and Gaza Palestinians in spring 2002, 66\% said army operations increased their backing for suicide bombings (39). By year's end, 73\% of Lebanese Moslems considered suicide bombings justifiable (38). This radicalization of opinion increases both demand and supply for martyrdom operations. A December 2002 UN report credited volunteers with swelling a reviving Al-Qaida in 40 countries (40). The organization's influence in the larger society-most significantly its directing elites-increases in turn.

\section{Priorities for Homeland Security}

The last line of defense against suicide terrorism-preventing bombers from reaching targets - may be the most expensive and least likely to succeed. Random bag or body searches cannot be very effective against people willing to die, although this may provide some semblance of security and hence psychological defense against suicide terrorism's psychological warfare. A middle line of defense, penetrating and destroying recruiting organizations and isolating their leaders, may be successful in the near term, but even more resistant organizations could emerge instead. The first line of defense is to drastically reduce receptivity of potential recruits to recruiting organizations. But how?

It is important to know what probably will not work. Raising literacy rates may have no effect and could be counterproductive should greater literacy translate into greater exposure to terrorist propaganda (in Pakistan, literacy and dislike for the United States increased as the number of religious $m a-$ drasa schools increased from 3000 to 39,000 since 1978) (27, 38). Lessening poverty may have no effect, and could be counterproductive if poverty reduction for the entire population amounted to a downward redistribution of wealth that left those initially better off with fewer opportunities than before. Ending occupation or reducing perceived humiliation may help, but not if the population believes this to be a victory inspired by terror (e.g., Israel's apparently forced withdrawal from Lebanon).

If suicide-bombing is crucially (though not exclusively) an institution-level phenomenon, it may require finding the right mix of pressure and inducements to get the communities themselves to abandon support for institutions that recruit suicide attackers. One way is to so damage the community's social and political fabric that any support by the local population or authorities for sponsors of suicide attacks collapses, as happened regarding the kamikaze as a by-product of the nuclear destruction of Hiroshima and $\mathrm{Na}-$ gasaki. In the present world, however, such a strategy would neither be morally justifiable nor practical to implement, given the dispersed and distributed organization of terrorist institutions among distantly separated populations that collectively number in the hundreds of millions. Likewise, retaliation in kind ("tit-for-tat") is not morally acceptable if allies are sought (41). Even in more localized settings, such as the IsraeliPalestinian conflict, coercive policies alone may not achieve lasting relief from attack and can exacerbate the problem over time. On the inducement side, social psychology research indicates that people who identify with antagonistic groups use conflicting information from the other group to reinforce antagonism (19). Thus, simply trying to persuade others from without by bombarding them with more self-serving information may only increase hostility.

Other research suggests that most people have more moderate views than what they consider their group norm to be. Inciting and empowering moderates from within to confront inadequacies and inconsistencies in their own knowledge (of others as evil), values (respect for life), and behavior (support for killing), and other members of their group (42), can produce emotional dissatisfaction leading to lasting change and influence on the part of these individuals (43). Funding for civic education and debate may help, also interfaith confidence-building through intercommunity interaction initiatives (as Singapore's government proposes) (35). Ethnic profiling, isolation, and preemptive attack on potential (but not yet actual) supporters of terrorism probably will not help. Another strategy is for the United States and its allies to change behavior by directly addressing and lessening sentiments of grievance and humiliation, especially in Palestine (where images of daily violence have made it the global focus of Moslem attention) (44) (Fig. 4). For no evidence (historical or otherwise) indicates that support for suicide terrorism will evaporate without complicity in achieving at least some fundamental goals that suicide bombers and supporting communities share.

Of course, this does not mean negotiating over all goals, such as Al-Qaida's quest to replace the Western-inspired system of nation-states with a global caliphate, first in Moslem lands and then everywhere (see supporting online text for history and agenda of suicide-sponsoring groups). Unlike other groups, Al-Qaida publicizes no specific demands after martyr actions. As with an avenging army, it seeks no compromise. But most people who currently sympathize with it might.

Perhaps to stop the bombing we need research to understand which configurations of psychological and cultural relationships are luring and binding thousands, possibly millions, of mostly ordinary people into the terrorist organization's martyr-making web. Study is needed on how terrorist institutions form and on similarities and differences across organizational structures, recruiting practices, and populations recruited. Are there reliable differences between religious and secular groups, or between ideologically driven and grievance-driven terrorism? Interviews with surviving Hamas bombers and captured Al-Qaida operatives suggest that ideology and grievance are factors for 
both groups but relative weights and consequences may differ.

We also need to investigate any significant causal relations between our society's policies and actions and those of terrorist organizations and supporters. We may find that the global economic, political, and cultural agenda of our own society has a catalyzing role in moves to retreat from our world view (Taliban) or to create a global counterweight (Al-Qaida). Funding such research may be difficult. As with the somewhat tendentious and self-serving use of "terror" as a policy concept (45), to reduce dissonance our governments and media may wish to ignore these relations as legitimate topics for inquiry into what terrorism is all about and why it exists.

This call for research may demand more patience than any administration could politically tolerate during times of crisis. In the long run, however, our society can ill afford to ignore either the consequences of its own actions or the causes behind the actions of others. Potential costs of such ignorance are terrible to contemplate. The comparatively minor expense of research into such consequences and causes could have inestimable benefit.

\section{References and Notes}

1. "Patterns of global terrorism" (U.S. Department of State, Washington, DC, May 2002); available at www.state.gov/s/ct/rls/pgtrpt/2001/. "The U.S. Government has employed this definition of terrorism for statistical and analytical purposes since 1983."

2. U.S. Code Congress. Admin. News, 98th Congress, 2nd Session, v. 2, par. 3077, 98 STAT. (19 October 1984).

3. Until 1983, official U.S. positions on "terror" followed the term's common meaning in use since the French Revolution, referring to state-sponsored terror. For example, under "sources relating to Operation Enduring Freedom and the struggle against terrorism," the U.S. Navy's Web guide on terrorism regularly links to Department of Defense articles on Iraq (www. history.navy.mil/library/guides/terrorism.htm).

4. The recent Guatemalan truth commission report singled out the U.S. Army School of the Americas (SOA), now at Fort Benning, Georgia, for counterinsurgency training that "had a significant bearing on human rights violations during the armed conflict." A 1998 human rights report released by the Guatemala Archdiocese Human Rights Office also linked SOA graduates in Guatemala's military intelligence (D-2, G-2) to a civilian-targeted campaign of kidnappings, torture, and murder that left tens of thousands dead. References available online through Network Solidarity with the People of Guatemala (NISGUA), "U.S. Army School of the Americas cited in Guatemalan Truth Commission Report," 17 July 2001; available at www.nisgua.org/articles/school_of_the_americas. htm.

5. B. Lewis, The Assassins (Basic, New York, 2002).

6. M. Robespierre, "Principes de morale politique," speech delivered to French National Convention, 5 February 1794; available at http://membres.lycos.fr/ discours/1794.htm.

7. A. Axell, Kamikaze (Longman, New York, 2002).

8. A precipitating event was the exiling of 418 Palestinians suspected of affiliation with Hamas (18 December 1992), the first mass expulsion of Arabs from Palestine since 1948.

9. Quran, chapt. 3, verses $140-146$.
10. Compare this statement with that of Hamas leader Abd Al-'Aziz Al-Rantisi, Al-Hayat (London-Beirut), 25 April 2002.

11. U.S. Department of Justice, Al Qaeda Training Manual, online release 7 December 2001; available at www.usdoj.gov/ag/trainingmanual.htm.

12. "Suicide terrorism: A global threat," Jane's BioSecurity (2002); available at www.janes.com/security/ international_security/news/usscole/jir001020_1_n. shtml.

13. B. Lewis, What Went Wrong (Oxford Univ. Press, New York, 2002). The notion of a distinct religious authority, or clergy, was traditionally alien to Islam. The de facto modern clergy recognized by Islamic suicide attackers includes mullahs of Pakistan and Afghanistan, as well as the 19th-century administrative office of ayatollah in Iran and the former Ottoman office of State Attorney, or mufti (e.g., in Palestine, Syria, and Arabia). Many in this "clergy" also oppose suicide bombing.

14. D. Malakoff, Science 295, 254 (2002).

15. D. Chapin et al., Science 297, 1997 (2002)

16. D. Von Drehle, Washington Post, 7 October 2002, p. A1. Warner's example of "rational deterrence" was the Cold War doctrine MAD (mutually assured destruction). MAD's key premise was the apparently irrational threat of guaranteeing one's own destruction in order to destroy the enemy.

17. Unitarian Universalist Association of Congregations, "Confronting anti-Arab or anti-Muslim sentiments," 21 September 2002; available at www.uua. org/uuawo/issues/respond/confront.html.

18. S. Milgram, Obedience to Authority (Harper \& Row, New York, 1974).

19. L. Ross, C. Stillinger, Negotiation J. 7, 389 (1991)

20. R. Clark, Crime in America (Simon \& Schuster, New York, 1970).

21. White House news release, 22 March 2002; available at www.whitehouse.gov/news/releases/2002/03/ 20020322-1.html.

22. J. J. Jai, Christian Science Monitor, 10 December 2001, p. 7.

23. G. Becker, Pol. Econ. 76, 169 (1968)

24. "They are youth at the peak of their blooming, who at a certain moment decide to turn their bodies into body parts... flowers." Editorial, Al-Risala (Hamas weekly), 7 June 2001

25. Sheikh Yussuf Al-Qaradhawi (a spiritual leader of the Muslim Brotherhood), Al-Ahram Al-Arabi (Cairo), 3 February 2001.

26. A. Krueger, J. Maleckova, NBER Working Paper no. w9074, National Bureau of Economic Research, Cambridge, MA, July 2002; available at http://papers. nber.org/papers/W9074.

27. T. Friedman, Longitudes and Attitudes (Farrar, Strauss, Giroux, New York, 2002). Leaders of Al-Qaida's international cells are often middle-class, Europeaneducated converts to radical Islam. Family histories indicate little religious fervor before emigration to a solitary existence in Europe and subsequent belonging to a local prayer group or mosque (available tapes preach a revolutionary end to daily, personal alienation through collective action to destroy perceived impediments to "restoring" Islam's values and dominance). As with other radical Islamic groups, ordinary cell operatives are often resident Middle East bachelors from middle-class families.

28. A. Merari, paper presented to Institute for Social Research seminar series, "The Psychology of Extremism," Univ. of Michigan, Ann Arbor, MI, 11 February 2002.

29. R. Ezekiel, The Racist Mind (Viking, New York, 1995).

30. N. Hassan, The New Yorker, 19 November 2001; available at www.newyorker.com/fact/content/ ?011119fa_FACT1.

31. B. Barber, Heart and Stones (Palgrave, New York, in press).

32. D. Brooks, The Atlantic Monthly 289 (6), 18 (June 2002); available at www.theatlanticmonthly.com/ issues/2002/06/brooks.htm.

33. Unlike people willing to blow themselves up, for frontline soldiers in an apparently hopeless battle, there usually remains hope for survival [G. Allport, J. Gillespie, J. Young, J. Psychol. 25, 3 (1948)]. The distance between no hope and some (however small) is infinite, which represents the ultimate measure of devotion that religions typically uphold as ideal. While commitment to die for nonkin cannot be rendered within standard theories of Expected Utility, there are moves theorists attempt, such as invoking "infinite utility." Using "infinite utility" to patch theories of rationality creates holes elsewhere in the system. Thus, expected utilities are usually weighted averages, which has scant sense when one term is infinite. The deeper point is that notions of maximization of anticipated benefits cannot account for such behaviors, and ad hoc moves to maintain rational utility at all costs result in a concept of rationality or utility doing little explanatory work. In sum, reliance on rational-choice theories may not be the best way to understand and try to stop suicide terrorism.

34. D. Rhode, A. Chivers, New York Times, 17 March 2002, p. A1.

35. "White Paper-The Jemaah Islamiyah Arrests," (Singapore Ministry of Home Affairs, Singapore, 9 January 2003); available at www2.mha.gov.sg. Recruitment and indoctrination into Jemaah Islamiyah are similar in other radical Islamic groups: "The first stage ... involved religious classes organised for a general mass.... The second stage ... involved identifying those who were captivated enough to find out more about the plight of Muslims in other regions. [Jl spiritual leader] Ibrahim Maidan identified potential members from those who were curious enough to remain after classes to enquire further. He engaged those students' interest and compassion and finally invited those he deemed suitable to join Jl. This recruitment process would usually take about 18 months. The few who were selected as members were made to feel a strong sense of exclusivity and self esteem .. a strong sense of in-group superiority."

36. In much the same way, the pornography, fast food, or soft drink industries manipulate innate desires for naturally scarce commodities like sexual mates, fatty foods, and sugar to ends that reduce personal fitness but benefit the manipulating institution. [S. Atran, In Gods We Trust (Oxford Univ. Press, New York, 2002)].

37. E. Sciolino, New York Times, 27 January 2002, p. A8.

38. "What the world thinks in 2002: How global publics view: Their lives, their countries, the world, America" Survey Rep., Pew Research Center, 4 December 2002); available at http://people-press.org/reports/ display.php3?ReportID $=165$.

39. Reuters News Service, 11 June 2002; accessed at http://story.news.yahoo.com/news?tmpl=story\&u=/ nm/20020611/wl_nm/mideast_palestini.

40. C. Lynch, Washington Post, 18 December 2002, p. A27.

41. R. Axelrod, W. Hamilton, Science 211, 1390 (1981).

42. M. Bazerman, M. Neale, Negotiating Rationally (Free Press, New York, 1991).

43. A. Eagly, S. Chaiken, The Psychology of Attitudes (Harcourt Brace, Fort Worth, TX, 1993).

44. One possibility is to offer and guarantee a clear resolution of "final status" acceptable to majorities of Israelis and Palestinians. Without clear resolution of final status before implementation of "confidence building" measures, with an understanding by all parties of what to expect in the end, it is likely that doubts about ultimate intentions will undermine any interim accord-as in every case since 1948. [S. Atran, Politics and Society 18, 481 (1990)].

45. N. Chomsky, 9-11 (Seven Stories Press, New York, 2001).

46. Thanks to D. Medin, N. Chomsky, R. Gonzalez, M. Bazerman, R. Nisbett, and reviewers.

Supporting Online Material www.sciencemag.org/cgi/content/full/299/5612/1534/ DC1

SOM Text 